\title{
Land use influence on organic carbon dynamics in soils of dryland agrolandscapes
}

\author{
Olga Soboleva ${ }^{1, *}$, Darya Vasilieva $^{2}$, Galina Koloshina $^{1}$, Tatiana Pimshina $^{1}$, and Alexey \\ Revyakin $^{1}$ \\ ${ }^{1}$ Rostov State Transport University (RSTU), 2 , Rostovskogo Strelkovogo Polka Narodnogo \\ Opolchenia sq., Rostov-on-Don, Russia, 344038 \\ ${ }^{2}$ Samara State Technical University, 244 Molodogvardeyskaya St., Samara, Russia, 443100
}

\begin{abstract}
Degradation of land used in agricultural production is studied. Different land use practices influence on the organic carbon content in arable soils of agrolandscapes on arid territories as an example. By the example of Rostov and Samara regions, the existing agricultural land ownership structure has been analyzed, and the dynamics of sown areas and humus content in arable soils has been studied. It is shown that in the course of the land reform there was a redistribution of land ownership, which is more pronounced in the Samara and Rostov regions than in the Russian Federation as a whole due to agricultural land predominance in the land fund. Agricultural landscapes in the provinces occupy most of the studied regions and are currently characterized by the processes of degradation. Private land ownership does not guarantee the implementation of measures to preserve and improve soil fertility without the development in the implementation of regulatory and legal framework for the rational use of land at the regional or federal level. Without the development of a system of comprehensive measures to organize the rational use of land at the federal and regional levels, landscape agro-ecological condition will continue to deteriorate.
\end{abstract}

\section{Introduction}

After the land reform that started in the Russian Federation in 1990, the organizational, legal, economic, technological and other bases of land use in the country have changed significantly. As a result of the land and agrarian reforms carried out simultaneously in Russia, radical changes in the sphere of land relations took place. There was introduced a variety of forms of land ownership, which had undoubtedly positive consequences [1]. However, under the conditions of imperfect land legislation, almost complete absence of land monitoring, undeveloped mechanisms of management and control (supervision) over the condition and use of land, negative phenomena that significantly worsen the condition of land resources have increased [2]. These phenomena include agrolandscape land degradation, which has widespread development and is a global environmental problem [3-6]. As a result of anthropogenic degradation and climate change, the area of soil resources suitable for agriculture is steadily decreasing with the ever-increasing Earth population [7-9].

\footnotetext{
*Corresponding author: sobolevao@yandex.ru
} 
Agricultural land degradation is an urgent problem for the Russian Federation [10-12]. According to the State Report on the State and Use of Land of the Russian Federation for 2019 (Rosreestr) it is noted that land degradation is observed almost everywhere in Russia [13]. The development of the land degradation process contradicts to the Russian Federation Food Security Doctrine, approved by Presidential Decree in January 2020. This document states that the national interest of the state in food security in the long term is, among other things, to restore and improve agricultural land fertility, prevent the reduction of such lands, their rational use, as well as the protection and preservation of agricultural land from water and wind erosion and desertification. At the same time there is a constant increase in the share of degraded lands and a decrease in agricultural land fertility due to their irrational use in agriculture [14].

Land degradation can occur as a result of natural and anthropogenic processes, the main ones being wind and water erosion, dehumification, overwatering, salinization, waterlogging and flooding, land disturbance, etc.

The organic carbon content (humus reserves and content) in soils of agricultural lands is one of the main indicators of soil fertility, a decrease in its content in the soil (degumification) refers to a chemical type of soil degradation, in which the decomposition of humus prevails over its resynthesis [9]. Degumification, in addition to a decrease in soil fertility, leads to the release of carbon dioxide from soils, and, consequently, to an increase in the greenhouse effect and global temperature.

Much attention has been paid to carbon accumulation (sequestration) in terrestrial ecosystems, but mainly the forest biomass is studied (for example, in the Kyoto Protocol program), the dynamics of carbon in soils of arid lands is not paid enough attention [15-16]. Yet drylands occupy a significant portion of the global surface and are home to more than one-third of the human population [17-18]. Changes in land use can both increase the emission of $\mathrm{CO} 2$ into the atmosphere and vice versa by enhancing the absorption and accumulation of carbon from the atmosphere and transferring it into soil humus.

This article aims to study land use influence on organic carbon dynamics in agrolandscapes soils on arid lands as an example. This issue is investigated on the example of two regions in the Russian Federation - Samara and Rostov regions.

\section{Materials and Methods}

The article analyzes the actual materials of publicly available national (state) reports on the state and use of lands in the Russian Federation as a whole and regional reports in the regions of Samara and Rostov as well as on the state and protection of the environment of the Russian Federation. In addition, we studied the historical analytical data obtained in regional chemical laboratories of the agrochemical service stations, as well as scientific publications on the analysis of the state of arable soils in the regions studied [19-22]..

The studied regions are located on European Russia, Samara region - on the border of the forest-steppe and steppe zones, and Rostov region - steppe and arid-steppe zones.

Samara region occupies an area of 53,56 thousand $\mathrm{km} 2$ and is situated in the south-east of the East-European plain in the Middle Volga region. The territory location on the border of steppe and forest-steppe determines the prevalence of leached, common and southern chernozems in the soil cover.

Rostov region has an area of 100.9 thousand $\mathrm{km} 2$, in the southern part of the East European Plain and partly in the North Caucasus region, occupies a vast territory in the Lower Don river basin. The soil cover is dominated by common and southern chernozems, as well as dark chestnut and chestnut soils.

Both studied regions are characterized by the predominance of agricultural land in the land fund structure: in the Samara region it occupies $75.9 \%$ of the territory, and in the Rostov 
region $-87.7 \%$. Arable lands prevail in the structure of agricultural lands (5812,9 thousand hectares or $70,8 \%$ of agricultural lands in Rostov region and 2858,5 thousand hectares or $70,3 \%$ in Samara region). Thus, both regions are characterized by developed agriculture, high agricultural development and arable land, so the environmental condition of the whole region largely depends on agricultural land. Analysis of materials from the Reports on the condition and use of land prepared by the Rosreestr departments for both Samara and Rostov regions revealed the presence of similar problems related to soil degradation in the studied regions.

It should be noted that degradation problems associated with intensive agricultural use of arid lands are acute throughout the globe. Drylands are identified by the Aridity Index (Al) established by the United Nations Environment Program (UNEP). This index is a dimensionless value, which is the ratio between annual precipitation and annual evaporation. The index value of 0.65 divides all lands of the planet into two classes: arid and wet. There are four subclasses of arid lands: hyper-arid (Al less than 0.05), arid (0.05-2), semi-arid (0.2$0.5)$ and sub-humid (0.5-0.65)..

There are different opinions about the area of drylands on a global scale. Their area is, according to various estimates, from $26.3 \%$ to $52.3 \%$. The most generally accepted values range from 40.8 to $41.3 \%$ of the global surface, with some classifications including dry boreal and polar regions in the dry land area of the world. The drylands class is subdivided into four subclasses according to the aridity index: sub-humid, semi-arid, arid and hyperarid.Drylands are very diverse. Even in deserts such as Namibia and Atacama, soil formation varies depending on distance from water sources, vegetation projective cover, soil-forming rocks, etc. This diversity can make it difficult to estimate carbon accumulation, soil uptake rates, and degradation losses.

At the same time, drylands are home to more than $35 \%$ of the world's population and contain up to $44 \%$ of the world's cultivated land. In general, cattle breeding is more widespread in these territories, rangelands provide food for half of the world's livestock, but they are gradually beginning to be converted into arable land. Land degradation processes, such as water and wind erosion, salinization, desertification, etc., widespread in the arid land zone, not only withdraw fertile lands from circulation, but also contribute to the reduction of the carbon reservoir in soil organic matter.

The observed warming of the planet's climate on the territory of the Russian Federation is manifested stronger than the average on the globe. According to the state report of the Ministry of Natural Resources and Environment of Russia for 2018, the average growth rate of the average annual air temperature in the territory of the Russian Federation from 1876 to 2018 was $0.47^{\circ} \mathrm{C}$ for 10 years, which is 2.5 times higher than the growth rate of the global temperature during this period $-0.17-0.18^{\circ} \mathrm{C}$. In 2018 in the Russian Federation there was an increase in the average annual air temperature by $1.58^{\circ} \mathrm{C}[19]$.

Climate warming can both increase dryland areas and aggravate land degradation problems.

Anthropogenic impact on the soil cover, intensive agricultural production, deforestation, urbanization, etc. leads to soil degradation, including a decrease in the content of organic carbon in soils [23-25]. Data from the 2018 report of the RF Ministry of Agriculture show that weakly humusy soils (37.0 million ha) prevail in the Russian Federation out of the 99.7 million ha surveyed during the year, accounting for $37.1 \%$ of the surveyed area. Soils with humus content below the minimum represent a significant proportion - 25.0 million ha or $25.1 \%$, medium-humus soils account for $26.3 \%$ or 26.2 million ha of the surveyed soils, while the share of highly humus soils does not exceed $11.4 \%$ or 11.4 million ha. The biggest part of arable lands with humus content less than minimal is situated in Samara region $(2,8 \mathrm{mln}$ ha or $99,2 \%)$, Orenburg region $(2,5 \mathrm{mln}$ ha or $41,2 \%)$, Kurgan region $(2,1 \mathrm{mln}$ ha or $86,2 \%)$, Rostov region $(2,0 \mathrm{mln}$ ha or $51,1 \%)$, Saratov region $(1,7 \mathrm{mln}$ ha or $29,9 \%)$; Stavropol Krai 
(1.3 million ha, or 32.1\%); Volgograd (1.3 million ha, or 23.1\%) and Chelyabinsk oblasts (1.1 million ha, or 44.1\%); Altai Krai (1.1 million ha, or 18.8\%) [26].

The land reform in the Russian Federation, which began 30 years ago, resulted in strong changes in land use. The transfer of agricultural land to private ownership was one of the goals of the land reform [1,25]. Along with the state ownership monopoly on land, such positive aspects of Soviet land use as soil protection and anti-erosion measures in large catchment areas, mandatory use of crop rotations, rationing of fertilizers, etc., were eliminated. [26-29]. According to statistical reporting (as of 01.01.2018) in the Russian Federation, $66.7 \%$ of agricultural land was in state and municipal ownership $(255,459.9$ thousand ha), $28.3 \%$ was owned by citizens (108,514.0 thousand ha), $5.0 \%$ was owned by legal entities (19,253.8 thousand ha) [13]. The distribution of agricultural lands of the Samara and Rostov regions by forms of land ownership is shown in the table (Table 1) [20-21].

Table 1. Ownership structure of agricultural land in Samara and Rostov regions.

\begin{tabular}{|l|c|c|c|c|}
\hline \multirow{2}{*}{ Region } & \multicolumn{3}{|c|}{ Private property (citizens and legal entities). thousand hectares (\% } & $\begin{array}{c}\text { State and } \\
\text { of category land area) }\end{array}$ \\
\cline { 2 - 4 } & $\begin{array}{c}\text { Total. } \\
\text { municipal } \\
\text { thousand } \\
\text { ownership. } \\
\text { hectares }\end{array}$ & $\begin{array}{c}\text { owned by citizens and their } \\
\text { associations. thousand } \\
\text { hectares (\% of category } \\
\text { land area) }\end{array}$ & $\begin{array}{c}\text { In the ownership of } \\
\text { legal entities. } \\
\text { thousand hectares (\% } \\
\text { of the land category) }\end{array}$ & $\begin{array}{c}\text { hectares (\% of } \\
\text { land category) }\end{array}$ \\
\hline $\begin{array}{l}\text { Rostov } \\
\text { region }\end{array}$ & $\begin{array}{c}7106.2 \\
(80.2 \%)\end{array}$ & $6101.5(68.8 \%)$ & $1004.7(11.3 \%)$ & $\begin{array}{c}1757.5 \\
(19.8 \%)\end{array}$ \\
\hline $\begin{array}{l}\text { Samara } \\
\text { region }\end{array}$ & $\begin{array}{c}2756.3 \\
(67.8 \%)\end{array}$ & $2459.6(60.5 \%)$ & $296.7(7.0 \%)$ & $\begin{array}{c}1310.9 \\
(32.2 \%)\end{array}$ \\
\hline
\end{tabular}

* Compiled by the authors according to the Report on the State and Use of Land in the Samara Region (2019) and the Report on the State and Use of Land in the Rostov Region (2020) [20-21].

In the Samara and Rostov oblasts, agricultural land is mostly privately owned by citizens. They mainly consist of land shares, and a big problem is the presence of unclaimed land shares (for example, in Samara Oblast their area is 86.9 thousand hectares). Unclaimed land shares are lands whose owners did not receive land ownership certificates in due time, or did not use their rights to dispose of.

\section{Results}

The level of organic carbon accumulation by soils can be influenced both by natural factors (e.g., climate, terrain, geological history, mineral composition, etc.) and by anthropogenic factors, which primarily include actual land use. Land use has a significant impact on vegetation cover, microclimate, microrelief, etc..

Different land use practices can influence the rate and amount of organic carbon accumulation in soils of arid lands. Under the conditions of widespread dehumidification of arable lands, the use of the most promising practices and agricultural technologies, in terms of possible carbon accumulation, is relevant. For example, it is shown [30] that no-tillage system of the main soil contributes to significant accumulation of organic matter.

Restoration of degraded lands is one of several paths of organic carbon accumulation in soils. Arid lands have a fairly high potential for carbon sequestration because they are currently characterized by high disturbance and are far from a state of equilibrium. There are various land use practices that significantly affect the level of carbon storage.

Organic carbon accumulation potential in the soil cover can be estimated by comparing the stock of organic carbon in soils at the minimum level of anthropogenic impact and at different types of land use. The most promising ways to increase carbon in arable soils of 
arid lands are the use of fertilizers, application of crop residues, as well as conservation or minimum tillage.

The negative impact on humus accumulation is caused by the cultivation of row crops (e.g., sunflowers) by almost all technologies, especially when using the system of tillage with deep mouldboard loosening [30].

Rostov and Samara regions are among the leading regions in the Russian Federation in terms of sunflower production, which is a raw material for an important export product sunflower oil. The cultivated area of this crop is constantly increasing (table. 2, 3) [31-32].

Table 2. Dynamics of sunflower crops in the Samara region*.

\begin{tabular}{|c|c|c|c|c|}
\hline Year & $\begin{array}{c}\text { Gross harvest. } \\
\text { thousand tons }\end{array}$ & $\begin{array}{c}\text { Sown sunflowers. } \\
\text { thousand hectares }\end{array}$ & $\begin{array}{c}\text { Yield. cwt per } \\
\text { hectare of } \\
\text { harvested area }\end{array}$ & $\begin{array}{c}\text { Total sown } \\
\text { area. thousand } \\
\text { hectares }\end{array}$ \\
\hline 1991 & 159.0 & 154.9 & 10.3 & 2628.4 \\
\hline 1995 & 125.1 & 188.0 & 6.7 & 2414.8 \\
\hline 2000 & 179.1 & 221.8 & 8.1 & 1959.6 \\
\hline 2005 & 248.5 & 294.9 & 8.9 & 1874.2 \\
\hline 2010 & 157.8 & 428.4 & 7.4 & 1830.7 \\
\hline 2015 & 537.2 & 550.4 & 11.1 & 2009.3 \\
\hline 2016 & 714.8 & 572.2 & 12.9 & 2046.9 \\
\hline 2017 & 674.8 & 595.3 & 12.4 & 2042.7 \\
\hline 2018 & 965.7 & 625.3 & 15.7 & 2096.7 \\
\hline 2019 & 1120.2 & 699.2 & 16.7 & 2113.6 \\
\hline
\end{tabular}

*Compiled by the authors on the basis of statistical compilations "Samara Statistical Yearbook", Samarastat, 2000-2020. [31].

Table 3. Dynamics of sunflower crops in the Rostov region*.

\begin{tabular}{|c|c|c|c|c|}
\hline Year & $\begin{array}{c}\text { Gross harvest. } \\
\text { thousand tons }\end{array}$ & $\begin{array}{c}\text { Sown sunflowers. } \\
\text { thousand hectares }\end{array}$ & $\begin{array}{c}\text { Yield. cwt per hectare } \\
\text { of harvested area }\end{array}$ & $\begin{array}{c}\text { Total sown } \\
\text { area. } \\
\text { thousand } \\
\text { hectares }\end{array}$ \\
\hline 2012 & 767.5 & 621.2 & 12.7 & 4290.3 \\
\hline 2016 & 774.9 & 560.4 & 14.3 & 4387.4 \\
\hline 2014 & 733.2 & 526.5 & 14.3 & 4365.6 \\
\hline 2015 & 826.1 & 532.8 & 15.7 & 4462.1 \\
\hline 2016 & 1261.2 & 594.7 & 21.4 & 4528.7 \\
\hline 2017 & 1429.5 & 714.9 & 20.5 & 4538.1 \\
\hline 2018 & 1341.1 & 713.6 & 19.0 & 4641.0 \\
\hline 2019 & 1807.0 & 739.4 & 24.6 & 4695.0 \\
\hline
\end{tabular}

* Compiled by the authors based on the materials of the statistical collections "Rostov Oblast in Figures", Rostovstat, 2016-2020 [32].

According to statistical yearbooks, Samara region has seen a significant increase in sunflower crops over the past 30 years (more than 4.5 times), for Rostov region this figure is much lower, but in the south of Russia sunflower has always been one of the main crops. According to Rosstat, this trend is typical for the whole Russian Federation, where from 2000 to 2018 there was an almost two-fold increase in the sunflower area (from 2623 thousand hectares in 2000 to 8160 thousand hectares in 2018) [33].

Analysis of sown area structure also shows that the area of perennial grasses, which contribute to the accumulation of humus in the soil, has decreased. For example, according to Rosstat, 18046 thousand hectares were sown with perennial grasses on farms of all categories in 2000, and in 2018 this figure decreased to 10558 thousand hectares. In general in the Russian Federation as a positive dynamics in terms of improving soil fertility, it should be noted the increase in the area of cultivation of leguminous crops, which enrich the soil 
with nitrogen (from 920 thousand ha from 2000 to 2754 thousand ha in 2018) during the same period. In the Samara region the dynamics of sown areas of perennial grasses and leguminous crops is presented in the table (tab. 4).

Table 4. Dynamics of sown areas of perennial grasses and leguminous crops in Samara and Rostov regions*.

\begin{tabular}{|c|c|c|c|c|}
\hline \multirow[t]{2}{*}{ Year } & \multicolumn{2}{|c|}{$\begin{array}{l}\text { Sown areas of leguminous } \\
\text { crops. thousand hectares }\end{array}$} & \multicolumn{2}{|c|}{$\begin{array}{c}\text { Sown area of perennial grasses (past years' } \\
\text { crops and current year's coverless crops). } \\
\text { thousand hectares }\end{array}$} \\
\hline & $\begin{array}{c}\text { Samara } \\
\text { region }\end{array}$ & $\begin{array}{l}\text { Rostov } \\
\text { region }\end{array}$ & Samara region & Rostov region \\
\hline 1991 & 86.0 & \multirow{5}{*}{ No data } & 201.3 & \multirow{5}{*}{ No data } \\
\hline 1995 & 32.3 & & 192.6 & \\
\hline 2000 & 14.0 & & 172.5 & \\
\hline 2005 & 21.1 & & 148.5 & \\
\hline 2010 & 50.2 & & 123.9 & \\
\hline 2015 & 77.4 & 82.9 & 127.6 & 133.0 \\
\hline 2016 & 80.6 & 112.0 & 126.6 & 137.2 \\
\hline 2017 & 103.4 & 136.5 & 132.3 & 126.0 \\
\hline 2018 & 136.3 & 216.1 & 135.2 & 116.2 \\
\hline 2019 & 104.2 & 135.9 & 122.9 & 110.1 \\
\hline
\end{tabular}

*Compiled by the authors according to the materials of statistical compilations "Samara Statistical Yearbook", Samarastat, 2000-2020 and "Rostov Region in Figures", Rostovstat, 2016-2020 [31-32].

Sown areas of leguminous crops in Samara region considerably decreased from 1991 to 2000 (from 86,0 thousand ha in 1991 to 14,0 thousand ha in 2000), but then restored and even increased some areas, which last three years, the data of which are published in statistical reports, occupy more than 100 thousand ha. Sowing of perennial grasses in Samara region has been steadily decreasing since 1991, which is mainly due to a significant reduction in the number of farm animals. A similar situation is observed in Rostov region.

Thus, the several-fold increase in sunflower crops and the decrease in perennial grass crops both in Russia as a whole and in some regions are negative factors in terms of rational land use and conservation of soil fertility. Despite the availability of the sowing area structure developed on a scientific basis for each region, which consists of a combination of the sowing area structure and the system of crop rotations, it is almost not used in practice due to the lack of legislative requirements for its observance developed at the regional and federal levels.

\section{Discussion}

In the territory of Samara and Rostov oblasts processes of degumification are observed practically on all soils of arable land and partially natural forage lands. In chernozems of Rostov region humus has decreased from 4.0 to $3.5 \%$, and in chestnut soils - from 2.8 to $2.35 \%$, in some areas the loss of humus up to $1.1 \%$, especially strong dehumification is manifested in irrigated lands. The main reason for the decrease in humus content is erosion processes [34].

Analysis of the materials of the Samara agrochemical service station showed that, since 1992, the balance of nutrients in the arable soils of Samara region has become negative [22]. Nutrient removal with the harvest began to significantly prevail over the return of nutrients to the soil. The increased loss of humus in recent years is associated primarily with a sharp decrease in the norms of organic and mineral fertilizers and the increased, in connection with this, processes of humus mineralization. The area of soils with high and elevated humus content is decreasing. Plots of arable land with very low humus content in soils appeared, 
which did not exist in the region before the land reform in 1987-1992. The average weighted humus content in arable soils decreased from $5.40 \%$ to $4.24 \%$. This means that soils have lost transformable organic matter in relation to its content in the virgin lands as a result of biological mineralization. This balance can be maintained by applying organic fertilizers, expanding the sowing of perennial grasses, as well as the incorporation of post-harvest residues. Decrease of humus layer is observed in areas with predominance of water erosion of soils. In the southeastern and southern regions, where dust storms periodically appear, the reduction of the humus layer of soils is less intense. At present, the overpowering chernozems $(\mathrm{A}+\mathrm{B}$ more than $120 \mathrm{~cm})$ have practically disappeared, and the share of medium-powered ones has increased. In addition to erosion, the soil profile reduction is also affected by gradual movement of soil by agricultural machinery from the tops and slopes.

The study of the dynamics of agrolandscapes in Samara and Rostov regions during the time of the land reform in the country has shown that there has been a significant decrease in their fertility. Humus reserves in the arable horizon have decreased, which is associated with a decline in farming culture, the predominance of extensive farming methods, and, consequently, a decrease in the amount of organic and mineral fertilizers used. According to statistical data in recent years, the amount of both mineral and organic fertilizers, slightly increased.

It should be noted the haphazard economic activities of many agro-industrial enterprises. Scientifically substantiated and tested in practice crop rotations and crop rotation schemes are absent or not used. The placement of crops in the agricultural landscape is carried out without taking into account the natural fertility of the soil and the extent of their influence on the volume of accumulation of organic matter in the arable horizon. There is practically no modern mapping material indicating the size of fields and fallow areas, maps of the steepness of slopes and the degree of erosion of areas, which leads to the treatment of soil without observing the basic rules of soil-protective farming. The current structure of sown areas does not contribute to the stabilization of soil fertility. The dominance of grain crops and sunflowers in the crops at low doses of mineral fertilizers significantly reduces the stock of nutrients in the soil.

The destruction of the system of land management that existed in the USSR, the comprehensive study of the state of soils and the development of measures for the rational use of agricultural land for each economic entity in compliance with the requirements to preserve and increase soil fertility, which were mandatory, led to such deplorable consequences. At present, the implementation of the developed system of conservation, reproduction and increase of soil fertility is not mandatory for landowners and land users. There is no legal framework, which could regulate the observance of crop rotation, application of necessary doses of mineral and organic fertilizers and other measures for the preservation and maintenance of soil fertility.

The current legislation of Russia (the Code of Administrative Offences of the Russian Federation) provides for bringing agricultural producers to administrative responsibility for failure to meet the established requirements and mandatory measures to improve, protect land and protect the soil from wind and water erosion and prevent other processes and other negative impacts on the environment that degrade the quality condition of land. But in practice it is quite difficult to prove the fact of committing such offense.

According to Rosselkhoznadzor data, the largest area of land where a decrease in agrochemical indicators determining soil fertility (acidity, mobile phosphorus content, exchangeable potassium content, organic matter) was detected during control and supervision activities was in Krasnoyarsk Territory, Moscow, Ulyanovsk, Lipetsk and Saratov Regions [35].

The main reason for the decrease in the level of fertility is mainly technological (operational) degradation of soils (land disturbance, physical degradation, agro-irrigation). 
In order to eliminate the identified violations of the requirements of the land legislation Rosselkhoznadzor issued 13,711 such prescriptions in 2019 [35].

Rosselkhoznadzor sent materials to the state authorities of the constituents of the Russian Federation to initiate the procedure of land withdrawal from unscrupulous owners on the area of 10.4 thousand hectares and informed about the necessity to cancel lease agreements due to inappropriate land use by lessees on the total area of 35.1 thousand hectares.

Judicial authorities made decisions on withdrawal of land from owners in respect of 41.7 thousand hectares. Decisions on termination of lease agreements on the area of 8.4 thousand hectares were made. On the area of 37.3 thousand hectares the owners have issued a voluntary renunciation of lands [35].

Taking into account the size of the sown areas of Russia and the number of land users, these figures are insignificant, and do not significantly affect the change in the overall situation in the country.

The large-scale spread of negative processes and the deterioration of the agro-ecological state of arable lands indicate that the allocation of budgetary funds for soil protection and environmental protection measures in local areas of the territory is not enough to correct the situation. It is necessary to develop comprehensive measures for the organization of rational land use by agricultural organizations.

\section{Conclusions}

1. The land reform in the Russian Federation, which began in 1991, led to a redistribution of land ownership, which mainly affected the category of agricultural land. In the Samara and Rostov oblasts this redistribution is more pronounced than in the Russian Federation as a whole due to the predominance of highly productive agricultural lands in the land fund.

2. Private ownership of land does not guarantee the implementation of measures to preserve and enhance soil fertility without the development in the implementation of regulatory and legal framework at the regional or federal level.

3. Agrolandscapes in the Samara and Rostov regions occupy most of the territory of the regions and are currently characterized by the processes of their stability and degradation, which are manifested in degumulation, decreased content of mobile phosphorus and potassium, activation of processes of water and wind erosion, salinization and desertification. Without the development of a system of integrated measures to organize the rational use of lands at the federal and regional levels, the agro-ecological state of landscapes will continue to deteriorate.

4. At present there is a need for the development of land management documentation on the rational use of agricultural land for each municipal district, mandatory for all economic entities carrying out their activities in the region. The municipal district is, in the authors' opinion, the minimum, sufficient, and stable unit for drafting such documentation. But it is impossible to carry out such work throughout the country without comprehensive management and financing of this process by the state.

5. To improve the effectiveness of the oversight function of the state in the management of land resources, it is necessary to develop and approve clear indicators of declining fertility, by which to monitor land on an ongoing basis, which will allow the timely detection of unscrupulous land users. 


\section{References}

1. V.N. Khlystun, Land reform: from state monopoly to diversity of ownership: Collective monograph (Publishing house of Samara Federal Research Center of RAS, Samara, 2020)

2. G. Khasaev, A. Vlasov, D. Vasilieva, V. Parsova, 17th International Scientific Conference Engineering for Rural Development, Proceedings", 630-634 (2018) DOI: 10.22616/ERDev2018.17.N244

3. Hao Li, Xiaohui Yang, Kebin Zhang, Global and Planetary Change 198, 103431 (2021) https://doi.org/10.1016/j.gloplacha.2021.103431

4. A.S. Yakovlev, O.A. Makarov, M.V. Evdokimova, S.S. Ogorodnikov, Soil science 9, 1167-1174 (2018)

5. A. Borrelli, P. Robinson, D.A. Fleischer et al., Nature Communications 8, 2013-2017 (2017) https://doi.org/10.1038/s41467-017-02142-7

6. A.A. Adenle, S. Eckert et al., Remote Sensing Applications: Society and Environment 19, 100360 (2020) https://doi.org/10.1016/j.rsase.2020.100360

7. C. Kosmas, O. Kairis, C. Karavitis et al., Environmental Management 54(5), 951-970 (2014) https://doi.org/10.1007/s00267-013-0109-6

8. S. Wijitkosum, International Soil and Water Conservation Research (2020) https://doi.org/10.1016/j.iswcr.2020.10.005

9. A.F. Chernysh, A.M. Ustinova, V.B. Tsyribko, A.N. Chervan, I.I. Kasyanenko, Soil Science and Agrochemistry 2(57), 7-18 (2016)

10. D. Vasilieva, V. Parsova, A. Vlasov, V. Tarbaev, Proceedings of the International Conference "Economic Science for Rural Development" 53, 240-247 (2020) DOI:10.22616/ESRD.2020.53.029

11. E.B. Dedova, B.A. Goldvarg, N.L. Tsagan-Mandzhiev, Arid Ecosystems 26.2(83), 63$71(2020)$

12. V.V. Pronko, D.Yu. Zhuravlev, T.M. Yaroshenko, N.F. Klimova, Chernozem soils degradation in agrolandscapes of the Volga steppe. New methods and results of landscape research in Europe, Central Asia and Siberia. Monograph (Publishing house: All-Russian research institute named by D.N. Pryanishnikov, Moscow, 2018)

13. Rosreestr. State (national) report on the state and use of land in the Russian Federation in 2018 (Rosreestr, Moscow, 2019) https://rosreestr.ru/

14. Decree of the President of the Russian Federation "On Approval of the Doctrine of Food Security of the Russian Federation. (No. 20 of 21.01.2020) (2020)

15. A. Hong, S. Yin, G. Piao, S. Dybzinski et al., Nature Sustainability 3, 694-700 (2020) https://doi.org/10.1038/s41893-020-0557-y

16. M. Lesiv, D. Schepaschenko, A. Moltchanova et al., Scientific Data 5, 180056 (2018) doi: $10.1038 /$ sdata.2018.56

17. P.K. Ghosh, S.K. Mahanta, Range Mgmt. \& Agroforestry 35(2), 173-181 (2014) ISSN 0971-2070

18. R. Sayre, M. Martin, D. Karagulle et al., World Terrestrial Ecosystems (2020) https://doi.org/10.1016/B978-0-12-409548-9.12474-1

19. State Report "On the State and Protection of the Environment of the Russian Federation in 2018" (Minprirody of Russia; NPP "Kadastr", Moscow, 2019) https://www.mnr.gov.ru/docs/gosudarstvennye_doklady/ 
20. Rosreestr Report on the state and use of lands in Samara Region (2019) https://rosreestr.ru/

21. Rosreestr Report on the state and use of lands in Rostov Region (2020) https://rosreestr.ru/

22. S.V. Obushchenko, V.B. Trots, Collection of scientific works of the International scientific-practical conference, 204-208 (2017)

23. V.N. Kudeyarov, Soil Science 9, 1049-1060 (2015)

24. V.N. Kudeyarov, Herald of the Russian Academy of Sciences 85(5), 397-401 (2015)

25. G. Khasaev, A. Vlasov, D. Vasilieva, V. Parsova, 17th International Scientific Conference Engineering for Rural Development, Proceedings 630-634 (2018) DOI: 10.22616/ERDev2018.17.N244

26. Report on the State and Use of Agricultural Lands of the Russian Federation in 2018 (FGBNU Rosinformagroteh, M., 2020)

27. A. Vlasov, D. Vasilieva, V. Tarbaev, 18th International Scientific Conference PEDTP. "Problems of Enterprise Development: Theory and Practice", 595-605 (2020) DOI: $10.15405 /$ epsbs. 2020.04 .76

28. A. Kondolskaya, D. Vasilieva, V. Parsova, D. Antropov, 18th International Scientific Conference Engineering for rural Development Proceedings 18, 774-779 (2019). DOI: 10.22616/ERDev2019.18.N108

29. G. Khasaev, A. Vlasov, Darya Vasilieva, V. Parsova, Baltic surveying. International scientific journal 10, 38-46 (2019) DOI: 10.22616/j.balticsurveying.2019.015

30. Y.S. Plitin, Humus state of leached chernozem in agrocenoses of the Azov-Kuban lowlands. Dissertation. D. in Agricultural Sciences (Krasnodar, 2014)

31. Statistical compilations "Samara Statistical Yearbook" (Samarastat, 2000-2020) https://samarastat.gks.ru/folder/34255

32. Statistical compilations "Rostov Oblast in Figures" (Rostovstat, 2016-2020) https://rostov.gks.ru/folder/30195

33. Federal State Statistics Service (2021) https://rosstat.gov.ru/

34. Zonal farming systems of the Rostov Oblast (for the period 2013-2020) (Ministry of Agriculture and Food of the Rostov Oblast, Rostov n/D, 2012) http://donagro.ru/FILES/2020/ZONSYSZEM/Sistema_zemled_do_2020_1.docx

35. Information on the implementation of state land supervision by Rosselkhoznadzor in 2019 (Rosselkhoznadzor, 2019) https://fsvps.gov.ru/fsvps/ground/useful.html 